strong and well-marked current up the eastern coast, passing between the Maniton Islands and the Michigan mainland, and ending in the reefs and rocks to the north of Little Traverse Bay. There is a current down the west coast, but at some distance offshore. In the space between its margin and the shore there are varying currents, sometimes to the northward and sometimes to the southward - on the whole rather from the south than from the north. There is a great but gentler whirl about Beaver Island in a direction contrary to the hands of a watch. The velocities found in these currents are greater than those found in Lake Superior, and this is especially true of the northern end of the current, which passes up along the east coast. In the case of the bottles which crossed Lake Michigan, the velocities obtained in the best cases varied from four to four and a half miles a day. Taking only the bottles which passed between Maniton Islands and the mainland, the velocities obtained varied from six and a half to ten a day. developed at no great distance from the south coast, and much farther from the north coast, which is cut by two long points extending out to about one-third of its width.

\section{LAKE ONTARIO.}

In Lake Ontario 56 bottles were recovered, of which 55 belonged to the season of 1892 , and one to that of 1893 . The directions taken by the bottles in the lake are somewhat similar to those in Lake Erie, but quite distinct from those of the upper lakes. There is a general current extending diagonally across the lake from opposite the mouth of Niagara River to the outlet near Kingston. The bottles exhibited a strong tendency to seek the east colst, passing down into the bay on which Sacketts Harbour, N.Y., is situated. There are evidences of a whirl in the western end of the lake, west of the meridian of Toronto.

The general conclusions of the paper relate only to the

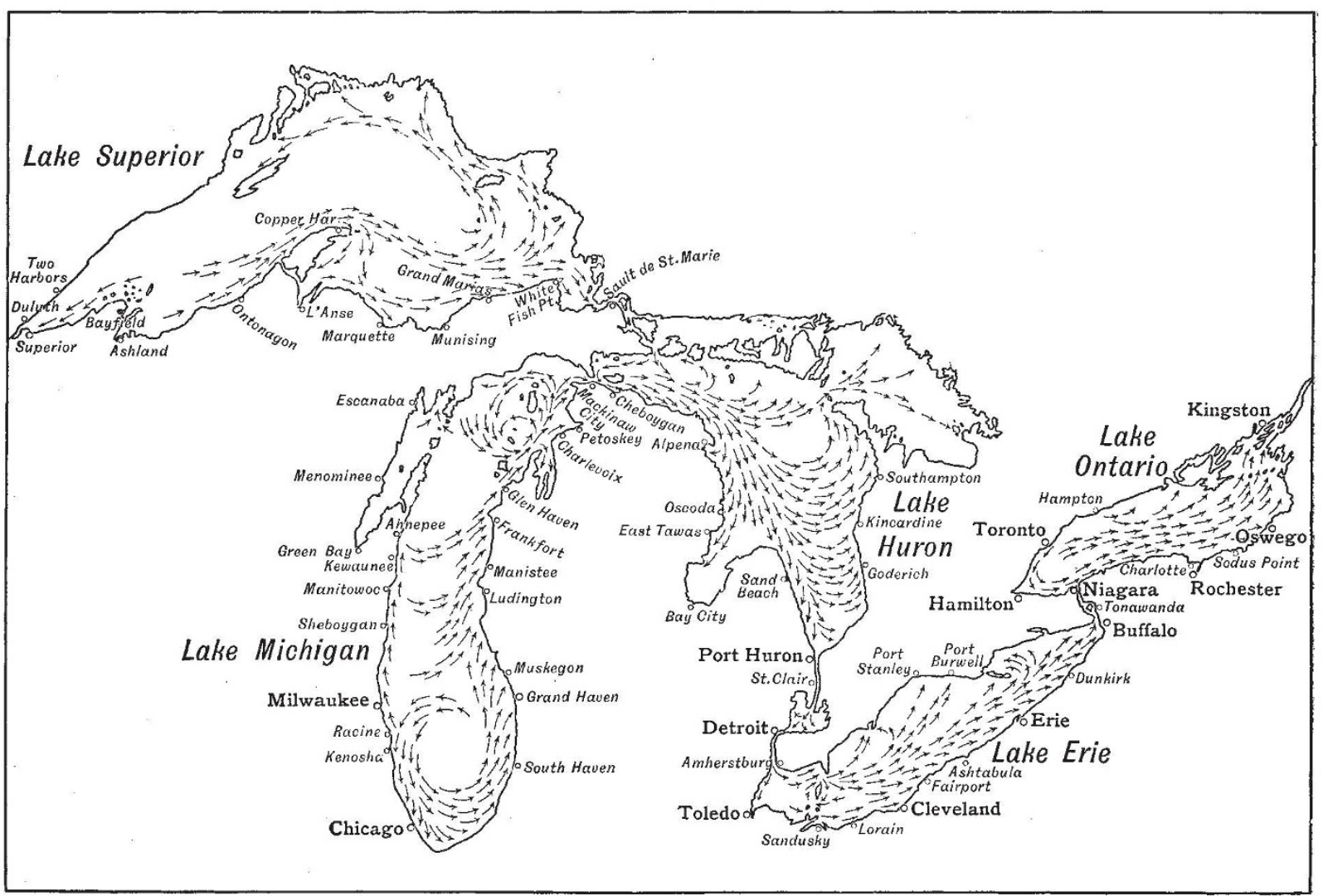

Thalker of Boutall se.

LAKE HURON.

In this lake 186 bottles were recovered, 142 for the season of I892, and forty-four for 1893 . From the courses of the bottles, it is concluded that the arrangements of currents is very much like that of Lake Mishigan. In this case, however, it seems that the main current is along the west coast, while in Lake Michigan it is along the east coast. It is found that in Lake Huron there is a strong current passing down the west coa-t and some little distance out, the whole length of the lake, turning on itself near the point of the lake, and passing up the east coast, possibly turning again along the north shore and rejoining the other current in the vicinity of Bois Blanc Island. A branch of this return extends into Georgian Bay.

\section{LAKE ERIE.}

The number of bottles recovered in Lake Erie was 96, of which 66 belonged to the season of 1892 , and 30 to 1893 . The general course of these bottles was ea,tward along the axis of the lake, with a tendency from point to point toward the coast. The indications are that the main current along the axis is best greater currents of the lakes. These currents must be sub stantially as indicated by the five or six hundred bottle-papers which have been recovered. There will, however, be some modifications due to season and direction of wind, but these modifications will be superficial, while the regular currents of the Great Lakes, which are described above, must be fairly persistent. Many of the modifications will be found in the bays and at the extreme angles of the lakes, and these remain for further investigation.

\section{SCIENTIFIC SERIALS.}

L'Anthropologie, tome v. No. I, January-February.-M. Emile Cartailhac contributes certain new facts with regard to the prehistoric history of the Pyrenees ; in the present number he describes some quartzites of the St. Acheul type that have been recently found in the cave of Herm (Ariège). The examin. ation of the animal remains was confided to M. Marce!lin Boule who com municates a short note on the remains of the Glutton (Gulo luscuss) and the Cave Lion (Felis spelaea) which were found No. 1277 , VOL. 49] 
there in association with the worked flints. The mandible of Felis spelea found in the cave of Herm presents characters intermediate hetween the lion and the tiger, and M. Boule would prefer to look upon this great cave cat as merely a polymorphous race of the modern lion; he suggests that it should be called Felis leo, race spelcea.-M. Salomon Reinach treats of sculpture in Europe prior to Greco-Roman influence; and M. G. Capus describes the ethnical migrations in Central Asia from a geographical point of view. From the Himalaya, southwards, to the Altai, northwards, the great mountain ranges of Central Asia form a series of practically parallel ridges running from east to west ; but from the $35^{\text {th }}$ to the $45^{\text {th }}$ parallels of latitude there is also a mountainous barrier extending from north to south, and separating the western plains from the valleys and plateaus of the east. This harrier has played an important part in determining the cisurse of the migration of nations and the distribution of the two great Asiatic races. It is formed more particularly by the Pamir platean, extending from the valley of the upper Indus as far as the Thian-Shan, to the north of the Trans-Alai range. The whole of the surrounding region is thus divided into three great sections-the Indo-Afghan, the Turanian (including Kashgar), and the Tibetan, and each of these three districts is characterised by certain physical features which distinguish it from the others. The Turanian slopes, with their grassy steppes and their arid deserts, possess a climate, a fauna, and a flora of great uniformity ; the absence of great forests, the predominance of pasturage over arable land, the rarity of summer rains, and the great variations of temperature, clearly distinguish this section irom the other two. On the high Tibetan plateaus which extend from the Kuen-lun to the Himalayas, the climatic conditions caused by the great altitude are, in general, so unfavourable to human life that they serve by themselves sufficiently to characterise this region. The plateaus and valleys of Afghanistan and the northern plains of India enjoy, on the other hand, a soil less unequal in richness, a climate less extreme, and a vegetation more abundant, thanks to the moisture that they receive from the south-west monsoons. The cultivation of the soil is more extensive, and is, at the same time, carried on with greater energy, so that arable land is less localised, and is in greater proportion to pasturage. But the aptitude of the soil to support nomadic cattle-breeders or sedentary agriculturists is an efficient factor in determining the routes chosen by the one and the other in their movements of migration or exodus ; and so we find that the sedentary Aryan who has trusted to agricultural pursuits from time immemorial has moved from the west to the south-east and the east ; while the Turco-Mongol, who has devoted himself to the raising of cattle and nomadism, has chosen the Turanian route from the east to the north-west and west.-M. R. Verneau describes a new human cranium from a lacustrine city. This is one of two crania found at Concise, by Dr. Gilbert, with some 1700 objects of bronze and stone, and is confidently attributed to the bronze age ; it is almost perfect with the exception of the lower jaw, and is remarkable for its extreme brachycephaly (9I.46).

The number of the Nuovo Giornale Botanico Italiano for April, and Nos. 2-4 of the Bullettino of the Italian Botanical Society, are almost entirely occupied with papers of special interest to Italian botanists, with whom the study of the galls produced on plants by insects occupies a large share of attention.

\section{SOCIETIES AND ACADEMIES. LONDON.}

Royal Microscopical Society, March 2I,-A. D. Michae], President, in the chair.-Mr. C. L. Curties exhibited and described a new form of photo-micrographic camera and drawing apparatus, designed by Prof. Edinger, and constructed by Herr E. Leitz.-Dr. W. H. Dallinger exhibited and described a new model microscope by Messrs. Swift.-Messrs. Watson and Sons exhibited a new super-stage plate fitted with two steel springs; they also showed a Ramsden screw micrometer and an Abbe camera lucida, both made in aluminitum. - Mr. R. T. Lewis described a scale insect from Natal, which he believed to be Trioza pellucida.-Mr. J. G. Grenfell exhibited and described specimens of Dicyemida, parasites found on the renal organs of cephalopods. - The President read a paper entitled "Notes on the Uropodinæ," a sub-family of the
Gamasidæ, one of the higher families of Acari. The classifi. cation was first considered, that by former authors was reviewed, and a new classification proposed suitable to the present state of knowledge on the subject. Two new genera were estab lished: one, Glyphopsis, for species with the body of irregular form sculptured on the dorsal surface, and with excavations for the legs on the ventral surface, which the author claimed as forming a natural group; the other, Trachetes, to replace Celceno, which name has failed by the operation of the law of priorities and for other reasons. Three new species were described, two from Cornwall and one from the Tyrol. One of the former, Glyphopsis Bostocki, is the largest and handsomest of known Uropodinæ; the Tyrolese species, Uropoda hamulifera, is also a remarkable creature. A list of the British species, which has not been attempted before, was then given, and the synonomy, which has fallen into great confusion, elucidated. The author then treated of the anatomy of Glyphopsis formi. caria, a curious species found some years since by Sir John Lubbock in the nests of the ant Sasius flavus, and lately found by $\mathrm{Mr}$. Michael in considerable numbers in Cornwall, in similar nests. This anatomy varies a good deal from that of other Uropodinæ previously investigated. The alimentary canal is more of the type of other Gamasidæ than of the Uropodinæ, the ventriculus being small and its creca long. The male genital organs also present special features; but the most remarkable novelties consist in a number of branched " racemose glands" of various sizes underlying the dorsal cuticle in fixed situations, and probably functioning as dermal glands; the coxal gland, which is attached to the second leg on each side, is also noticeable specially for the extremely large size and fleshy nature of its duct. It is probably the most striking coxal gland yet found in the Acarina.

Victoria Institute, March 19.--Sir G. G. Stokes, Bart., F.R.S., President, in the chair.-On a possible cause for the origin of the tradition of the flood, by Dr. Prestwich, F. R.S. The paper described at considerable length the various phenomena which came under the author's observation during long years of geological research throughout Europe and the coasts of the Mediterranean. He concluded by giving the reasons why he considered that these were "only explicable upon the hypothesis of a widespread and short submergence of continental dimensions, followed by early re-elevation, and this hypothesis satisfied all the important conditions of the problem." The age of man was held to be divided into Palæolithic and Neolithic, and he considered rightly so. He concluded by saying that thus there seemed cause for the origin of that widespread tradition of a flood. The paper was followed by reference to a communication from Sir W. Dawson, F.R.S., who welcomed the paper as confirming his conclusion, come to on geological and palæontological grounds, as to a physical break in the anthropic age. The evidence for this was afforded by the cave remains and from a vast quantity of other sources. The discussion which ensued was joined in by a considerable number, including Dr. Woodward, F.R.S., Prof. T. R. Jones, F.R.S., T. McK. .Hughes, F.R.S., E. Hull, F.R.S., and Sir H. Howorth, F.R.S.

Zoological Society, April 3.-Sir W. H. Flower, K.C.B., F.K.S., President, in the chair. - The Secretary read a report on the additions that had been made to the Society's menagerie during the month of March I894.-Dr. Günther exhibited and made remarks on some specimens of the American Lepidosiren (Lepidosiren paradoxa) from the Upper Rio Paraguay, collected by Dr. Bohls.-Captain H. G. C. Swayne, R.E., gave a description of the physical features of Somaliland, and an account of the expeditions he had made into the interior of that country during the past nine years, pointing out the localities in which the larger mammals were usually met with. The paper was illustrated by the exhibition of a large series of well-mounted heads of the various species of antelopes and other animals of Somaliland.-Mr. O. Thomas read a paper on the dwarf antelopes of the genus Madoqua, in which three species from Somaliland were described as new, and named $M$. swaynei, $M$. phillipsi, and $M$. guentheri. A revised classification of the six known species of this genus of antelopes was added.-Mr. R. T. Coryndon gave an account of his pursuit of the white or Bur* chell's rhinoceros (Rhinoceros simus) in Mashonaland, and of the way he had obtained the specimens which would shortly be placed in the British Museum, the Tring Museum, and the Cambridge University Museum (see p. 584).-A communication

Nก. I 277 , vor.. 49] 